\title{
Powdered tucupi condiment: sensory and hygroscopic evaluation
}

\author{
Telma dos Santos COSTA ${ }^{1}$, Juliana Rodrigues do CARMO ${ }^{1}$, Rosinelson da Silva PENA ${ }^{1,2 *}$
}

\begin{abstract}
Tucupi is a fermented liquid obtained from cassava (Manihot esculenta Crantz), very much appreciated by the traditional cuisine of Northern Brazil. However, there are no scientific reports on its use in the formulation of products. Thus, the present study aimed to elaborate a powdered condiment with tucupi, as well as to assess the product's sensory acceptability and its hygroscopic behavior. The powdered tucupi used in the formulation of the condiment was obtained by drying in a spray dryer. The product underwent sensory evaluation for its acceptability regarding the attributes of color, aroma, flavor, and overall impression and a purchase intention test was applied by hedonic scale. The acceptability index was $80 \%$ for overall impression and the purchase intention test indicated that $94 \%$ of the judges would be willing to buy the product. The product's moisture sorption isotherms presented type-II behavior for adsorption and type-III for desorption, at $25^{\circ} \mathrm{C}$. The hygroscopic behavior indicated that the product is more susceptible to spoilage changes when stored in an environment with relative humidity above $60 \%$ and the Peleg model showed an excellent performance on predicting the product's moisture sorption isotherms.
\end{abstract}

Keywords: Manihot esculenta; cassava wastewater; innovation; acceptability test.

Practical Application: A powdered condiment prepared with tucupi was obtained and characterized.

\section{Introduction}

Cassava (Manihot esculenta Crantz) is one of the 100 species of trees, shrubs and herbs from the Manihot genus. Although some studies indicate that cassava has several centers of origin, others indicate that the cultivated species were originated in the southern edge of the Brazilian Amazon (Lebot, 2009).

Between 1980 and 2011, the global harvested area of cassava expanded from 13.6 million to 19.6 million hectares, which was considered as the biggest increase percentage among the world's five major food crops. In that same period, world's cassava production doubled from 124 million to 252 million tons (Food and Agriculture Organization of the United Nations, 2013). In Brazil, the estimated production of cassava was 23.7 million tons in 2016, with an increase of $4.2 \%$ over 2015 . This increase is mainly due to the fact that the cassava plantations demand smaller investments than other agricultural species (Companhia Nacional de Abastecimento, 2016).

The cuisine of the Brazilian state of Pará, a rich part of the Amazon gastronomy is a veritable panorama of contrasting flavors. It is fancy and exotic and, in order to savor some dishes, it is necessary to be free of any dietary prejudice. Among the most famous and appreciated dishes of the traditional cuisine of Northern Brazil, tacacá, duck in tucupi sauce and Parás rice stand out, all of them prepared with typical raw materials of the region (Santos \& Pascoal, 2013). One indispensable ingredient to prepare those delicacies is tucupi, a yellow fermented liquid product obtained from cassava (Agência de Defesa Agropecuária do Estado do Pará, 2012).
Powders obtained from concentrated plant extracts represent a promising market since they maintain the natural characteristics of the raw material, they are more chemically and microbiologically stable and easily reconstituted. Those products may be used to add color and flavor to several foods (Bhandari et al., 2007). Moreover, a dry product has lower volume and mass, which entails lower costs with storage, packaging and transportation (Dova et al., 2007; Doymaz, 2011). In this context, using powdered tucupi to prepare a powdered condiment may represent a technological alternative to preserve and add value to tucupi.

Condiments or seasonings are defined as products obtained from the mixture of spices and other, fermented or unfermented ingredients used to add flavor or aroma to foods and beverages. They may be designated as "condiment prepared", followed by the ingredient that characterizes the product (Brasil, 2005). Condiments can improve the palatability of monotonous diets, which are composed by staple foods (Viuda-Martos, et al., 2011; Spohrer et al., 2013).

When a biological material is exposed to an environment with certain relative humidity $(\mathrm{RH})$, it loses or gains water to adjust its moisture to a condition of equilibrium with the environment. That occurs when the water vapor pressure on the material's surface is equal to the water vapor pressure of the air surrounding it (Treyball, 1980). In this context, the knowledge of hygroscopicity of products with low moisture, such as powders, is crucial to establish their behaviors when exposed to an environment with relative humidity that favor the water gains

${ }^{1}$ Programa de Pós-graduação em Ciência e Tecnologia de Alimentos, Instituto de Tecnologia, Universidade Federal do Pará - UFPA, Belém, PA, Brazil

${ }^{2}$ Faculdade de Engenharia de Alimentos, Instituto de Tecnologia, Universidade Federal do Pará - UFPA, Belém, PA, Brazil

*Corresponding author: rspena@ufpa.br 
or losses (Jaya \& Das, 2004; Borges et al., 2009). To that end, moisture sorption isotherms are used, which allow to establish processing conditions and to define the packaging material to be used, as well as assessing the product's stability during storage and shipping (Samapundo et al., 2007; Tunç \& Duman, 2007; Corrêa et al., 2014).

Based on the above considerations, the present study aimed to prepare and to evaluate the microbiological and sensory characteristics of a powdered condiment with tucupi, as well as to assess the physicochemical characterization and hygroscopic behavior of the product.

\section{Materials and methods}

\subsection{Raw material}

A commercial unseasoned tucupi with $5 \%$ solids was used in the condiment preparation, as well as refined sugar (sucrose) (Camil, Sertãozinho, Brazil), salt (Unisal, Mossoró, Brazil), and dried garlic powder and dried onion powder (Mariza, Castanhal, Brazil).

\subsection{Tucupi drying}

In a first stage of the process, the commercial tucupi was concentrated down to $25 \%$ solids in a rotary evaporator at $70{ }^{\circ} \mathrm{C}$ and $31.2 \mathrm{kPa}$ (vacuum). In this concentrated tucupi, there were added 30\% maltodextrin $20 \mathrm{MD}$ (Cargill Agrícola S.A.) on the dry basis, and the mix was homogenized in a magnetic stirrer (Mod.712, Frisatom, São Paulo, Brazil) until complete dissolution of the maltodextrin. Then, the mix was injected at room temperature $\left(\approx 25^{\circ} \mathrm{C}\right)$ in a mini spray dryer (B-290, Buchi Labortechnik AG, Flawil, Switzerland). The equipment operation conditions were: atomizer nozzle with $0.7 \mathrm{~mm}$ gap, compressed air flow at $33 \mathrm{bar}$, feeding rate of $10 \mathrm{~mL} / \mathrm{min}$, input air temperature of $180^{\circ} \mathrm{C}$, and output air temperature of $90^{\circ} \mathrm{C}$. The process conditions were established in preliminary assays and the powdered tucupi presented $4.3 \%$ moisture (wet basis). The moisture content was determined according to Association of Official Analytical Chemists (2010) (method 925.09).

\subsection{Condiment obtaining}

Sachets with $12.5 \mathrm{~g}$ of the powdered condiment containing $56 \%$ powdered tucupi, $12 \%$ salt, $24 \%$ sugar, $4 \%$ dried garlic powder, and $4 \%$ dried onion powder were obtained. The product was obtained by simple mixture of the solid fractions. Since powdered tucupi with $4.3 \%$ moisture and $30 \%$ maltodextrin (db) was used, $4.7 \mathrm{~g}$ of the solids in each sachet came from tucupi. This way, dissolving a sachet of the product in $100 \mathrm{~mL}$ of water will result in a product with $4.7 \%$ solids, which comes only from tucupi and corresponds to the solids content found in commercial tucupi. Chisté et al. (2007) found solids contents in commercial tucupi products ranging from 3.9 to $5.4 \%$.

\subsection{Physicochemical characterization}

The condiment underwent analyses of moisture (method 925.09), ashes (method 923.03), lipids (method 920.85), proteins (nitrogen-protein correction factor of 6.25) (method 920.87), and chlorides (method 935.47) as described by the Association of Official Analytical Chemists (2010). The $\mathrm{pH}$ was determined through direct measurement with a digital $\mathrm{pH}$ meter (HI 2223, Hanna, Brazil) and water activity $\left(\mathrm{a}_{\mathrm{w}}\right)$ was determined at $25^{\circ} \mathrm{C}$ with a digital thermohygrometer (AquaLab 4TE, Decagon, USA). The total carotenoid content was determined by spectrophotometry at a reading of $450 \mathrm{~nm}$, using petroleum ether as solvent (specific absorbance at 2,592) according to Rodriguez-Amaya (2001). The results were expressed in $\mu$ g of $\beta$-carotene/g product. To calculate the product's energy value, the total carbohydrate content was determined from the difference (100 - (moisture + ashes + lipids + proteins $)$ (Brasil, 2003). Instrumental color was determined by a Chroma Meter CR 400 Konica-Minolta digital colorimeter (Japan) using the CIE Lab system. The parameters $L^{*}$, which defines luminosity ( $L^{*}=0$ black; $L^{*}=100$ white), and $a^{*}$ and $b^{*}$, responsible for chromaticity $\left(+a^{*}=\right.$ red and $-a^{*}=$ green $/+b^{*}=$ yellow and $-b^{*}=$ blue $)$, were assessed. Additionally, $\mathrm{a}^{\star}$ and $\mathrm{b}^{\star}$ parameters were used to calculate the chroma $\left(\mathrm{C}^{\star}\right)$ value, which is responsible for the saturation of the color $(0=$ neutral color and $60=$ vivid color $)$ and hue angle $\left(\mathrm{h}^{\star}\right)$ value, that is defined as basic unit of color $\left(0^{\circ}\right.$ and $360^{\circ}=$ red, $90^{\circ}=$ yellow, $180^{\circ}=$ green and $270^{\circ}=$ blue $)$ (Sève, 1991; McLellan et al., 1995; Smith, 2014). All analyses were performed in triplicate and the results were presented as the replicates mean.

\subsection{Microbiological evaluation}

The microbiological quality of the obtained product was evaluated according to the legislation for sauces and condiments assessing coliforms at $45^{\circ} \mathrm{C}$ and Salmonella (Brasil, 2001), which is recommended by the technical regulation for spices, condiments and sauces (Brasil, 2005).

\subsection{Sensory evaluation}

The sensory analysis was performed through the approval of the Research Ethics Committee of the Federal University of Pará (CEP/ICS/UFPA), under protocol no. 1.123.945. The product's sensory evaluation was performed by 100 untrained judges of both sexes, between 18 and 60 years old, who declared to appreciate tucupi. The test was carried out at UFPA's Sensory Analysis Laboratory according to Della Lucia (2008) and Minim (2013).

Parboiled rice was used as the vehicle in the product's sensory evaluation. The rice was cooked in water with $10 \%$ of the condiment, calculated over the rice amount. As a comparison, a rice sample was cooked using one part water, one part commercial tucupi, and salt. The proportions of the powdered condiment and of the commercial tucupi used were defined in preliminary assays. The samples were served hot $\left(\approx 40^{\circ} \mathrm{C}\right)$ in $50 \mathrm{~mL}$ plastic containers, which were randomly coded with three-digit numbers. $5 \mathrm{~g}$ of each sample were monadically served and the judges were asked to drink water between samples to prevent sensory fatigue. An acceptance test was applied to asses the product regarding color, aroma, texture, flavor, and overall impression. This test used a nine-point hedonic scale ranging from "disliked extremely" (score 1) to "liked extremely" (score 9). 
The data analysis used frequency distribution for the sensory scores of each attribute and for overall impression according to the following acceptance ranges (Della Lucia, 2008): rejection region, comprising scores from 1 to 5 (located between the hedonic terms "disliked very much" and "indifferent"), which indicated that the judges did not like the sample; and the acceptance region, comprising scores from 6 to 9 (located between the hedonic terms "liked slightly" and "liked extremely"), which indicated that the judges liked the sample.

The acceptability index (AI) (Equation 1) for the overall impression and purchase intention of the product were also assessed. This test used a five-point scale from "certainly would not buy" (score 1) and "certainly would buy" (score 5) (Minim, 2013).

$A I(\%)=A_{m} \cdot 100 / B$

where: $\mathrm{A}_{\mathrm{m}}=$ mean score obtained for the product and $\mathrm{B}=$ maximum score given to the product.

\subsection{Hygroscopic evaluation}

The hygroscopic behavior of the powdered condiment was assessed based on moisture sorption isotherms aiming to establish storage and maintenance conditions for the product. The moisture sorption data were obtained in a Vapor Sorption Analyzer (VSA) (Aqualab VSA, Decagon, WA, USA). To that end, $500 \mathrm{mg}$ of the sample were weighed on the equipment's micro analytical balance in a stainless steel capsule. The equipment was programmed to obtain data in an adsorption-desorption cycle at $25^{\circ} \mathrm{C}$ for a range from 0.1 to $0.9 \mathrm{a}_{\mathrm{w}}$, using the dynamic vapor sorption (DVS) method. The equilibrium data were obtained in $0.05 \mathrm{a}_{\mathrm{w}}$ intervals and the equilibrium condition was established to happen when two consecutive measurements yielded a ratio between mass variation and time variation $(\Delta \mathrm{m} / \Delta \mathrm{t})$ below 0.05 . After the analysis, the dry weight of the sample contained in the capsule was determined in an oven at $105^{\circ} \mathrm{C}$ (Association of Official Analytical Chemists, 2010).

The monolayer value $\left(\mathrm{m}_{\mathrm{o}}\right)$ was determined for the adsorption and desorption processes using linear regression based on the linearized form of the BET equation (Equation 2) (Brunauer et al., 1938).

$\frac{\mathrm{a}_{\mathrm{w}}}{\left(1-\mathrm{a}_{\mathrm{w}}\right) \cdot m}=\frac{1}{m_{o} \cdot c}+\frac{(\mathrm{c}-1)}{m_{o} \cdot c} \cdot a_{w}$

where: $\mathrm{m}=$ moisture $\left(\mathrm{g} \mathrm{H}_{2} \mathrm{O} / 100 \mathrm{~g} \mathrm{db}\right) ; \mathrm{a}_{\mathrm{w}}=$ water activity (non-dimensional); $\mathrm{m}_{\mathrm{o}}=$ monolayer moisture $\left(\mathrm{g} \mathrm{H}_{2} \mathrm{O} / 100 \mathrm{~g} \mathrm{db}\right)$, and $\mathrm{C}=$ constant related to the sorption heat.

The following proposed equation (Equation 3) was used to estimate the storage time of the product. This equation involves both packaging and product properties, which are easily determined.

$t=\frac{M}{100 \Phi A}\left[m_{\max }-\left(\frac{m_{\max }}{100}+1\right) X\right]$ where: $\mathrm{t}=$ storage time of the product (days); $\mathrm{M}=$ product mass in packaging $(\mathrm{g}) ; \mathrm{m}_{\max }=$ maximum moisture to be reached by the product $\left(\mathrm{g} \mathrm{H}_{2} \mathrm{O} / 100 \mathrm{~g} \mathrm{db}\right) ; \mathrm{X}=$ initial product moisture ( $\mathrm{g} \mathrm{H}_{2} \mathrm{O} / 100 \mathrm{~g}$ ); $\Phi=$ water vapor permeability of the packaging material ( $\mathrm{g} \mathrm{H}_{2} \mathrm{O} / \mathrm{m}^{2}$.day); $\mathrm{A}=$ packaging contact area $\left(\mathrm{m}^{2}\right)$.

The fits of the mathematical models presented in Table 1 were assessed to the experimental data of moisture sorption of the product.

\subsection{Statistical analysis}

The results of the sensory analysis were assessed using Student's $t$ test and differences were considered significant if $\mathrm{p} \leq 0.05$. The software Statistica for Windows version 7.0 was used to assess the data. The same software was used in the non-linear regression analysis for the mathematical model fits to the sorption data. To that end, the estimation methodology by Levenberg-Marquardt and convergence criterion of $10^{-6}$ were used. The goodness of fit of the each model was assessed using the coefficient of determination $\left(\mathrm{R}^{2}\right)$, root mean square error (RMSE) (Equation 4), and the mean standard deviation (P) (Equation 5). The model fit was considered satisfactory when $\mathrm{R}^{2}$ value was closest to 1, RMSE value was closest to zero and $P$ value was below 10\% (Lomauro et al., 1985; Arslan \& Togrul, 2005).

$\mathrm{RMSE}=\left[\frac{1}{N} \sum_{i=1}^{N}\left(m_{\mathrm{exp}}-m_{\text {pred }}\right)^{2}\right]^{1 / 2}$

Table 1. Mathematical models used to predict the sorption isotherms.

\begin{tabular}{|c|c|c|}
\hline Model & Equations & No. of parameters \\
\hline Halsey & $m=\left[\frac{-a}{\ln a_{w}}\right]^{\bar{b}}$ & 2 \\
\hline Henderson $^{\mathrm{a}}$ & $m=\left[\frac{-\ln \left(1-a_{w}\right)}{a}\right]^{\frac{1}{b}}$ & 2 \\
\hline Kuhn $^{a}$ & $\mathrm{~m}=-\frac{\mathrm{a}}{\ln \mathrm{a}_{\mathrm{w}}}+\mathrm{b}$ & 2 \\
\hline Mizrahi $^{\mathrm{a}}$ & $\mathrm{a}_{w}=\frac{\mathrm{a}+\mathrm{m}}{\mathrm{b}+\mathrm{m}}$ & 2 \\
\hline Oswin $^{\mathrm{a}}$ & $m=a\left[\frac{a_{w}}{1-a_{w}}\right]^{b}$ & 2 \\
\hline Ferro-Fontan ${ }^{\mathrm{b}}$ & $m=\left[\frac{a}{\ln \left(b / a_{w}\right)}\right]^{\frac{1}{c}}$ & 3 \\
\hline $\mathrm{GAB}^{\mathrm{c}}$ & $m=\frac{m_{o} \cdot c \cdot k \cdot a_{w}}{\left[\left(1-k \cdot a_{w}\right) \cdot\left(1+(c-1) \cdot k \cdot a_{w}\right)\right]}$ & 3 \\
\hline Peleg $^{\mathrm{d}}$ & $m=a \cdot a_{w}^{c}+b \cdot a_{w}^{d}$ & 4 \\
\hline
\end{tabular}

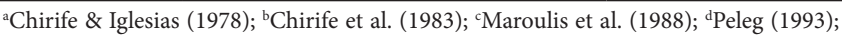
$\mathrm{m}=$ moisture $\left(\mathrm{g} \mathrm{H}_{2} \mathrm{O} / 100 \mathrm{~g} \mathrm{db}\right) ; \mathrm{a}_{\mathrm{w}}=$ water activity; $\mathrm{m}_{\mathrm{o}}=$ monolayer moisture ( $\mathrm{g} \mathrm{H}_{2} \mathrm{O} / 100 \mathrm{~g} \mathrm{db}$ ); a, b, c, k, $\mathrm{n}=$ constants. 
$\mathrm{P}=\frac{100}{N} \sum_{i=1}^{N} \frac{\left|m_{\text {exp }}-m_{\text {pred }}\right|}{m_{\text {pred }}}$

where: $\mathrm{m}_{\exp }=$ experimental moisture $\left(\mathrm{g} \mathrm{H}_{2} \mathrm{O} / 100 \mathrm{~g} \mathrm{db}\right)$; $\mathrm{m}_{\text {pred }}=$ moisture predicted by the model $\left(\mathrm{g} \mathrm{H}_{2} \mathrm{O} / 100 \mathrm{~g} \mathrm{db}\right)$; $\mathrm{N}=$ number of experimental measurements.

\section{Results and discussion}

\subsection{Product characterization}

The powdered tucupi condiment presented the following composition: $7.13 \%( \pm 0.43)$ moisture, $3.01 \%( \pm 0.51)$ lipids, $9.55 \%( \pm 0.23)$ crude protein, $17.51 \%( \pm 0.36)$ ashes, $14 \%( \pm 0.52)$ chlorides, $62.8 \%( \pm 4.30)$ total carbohydrates, and $23.36 \mu \mathrm{g} / \mathrm{g}$ $( \pm 5.37) \beta$-carotene. Since this type of product is usually sold in $5 \mathrm{~g}$ packages, one sachet of the powdered tucupi condiment would have an energy value of $16 \mathrm{kcal}$.

The product presented $\mathrm{pH}=4( \pm 0.01)$ and $\mathrm{a}_{\mathrm{w}}=0.24( \pm 0.01)$, which ensures its microbiological stability (Chirife \& Favetto, 1992) and it may be stored at room temperature. In addition, the values of the instrumental color parameters $L^{\star}(68.20 \pm 0.21)$, $a^{\star}(4.36 \pm 0.06)$, and $b^{*}(41.55 \pm 0.26)$ indicated that the product had a strong tendency to yellow color and a slight tendency to red color, with good luminosity. The $C^{\star}$ value $(41.39 \pm 0.13)$ showed that the product presented a vivid color and the $h^{*}$ value $(83.98 \pm 0.06)$ confirms the yellow color of the condiment, since hue angle value is close to $90^{\circ}$. The product's yellow color is attributed to the presence of carotenoids in tucupi. According to the literature, yellow cassava varieties, used to obtain tucupi, present $5.29 \mu \mathrm{g} / \mathrm{g}$ carotenoids on average (Ssemakula et al., 2007).

\subsection{Microbiological evaluation}

Values below $3 \mathrm{MPN} / \mathrm{g}$ for coliforms at $45^{\circ} \mathrm{C}$ and the absence of Salmonella indicated that the tucupi condiment met the current microbiological standards for this type of product (Brasil, 2001) and is safe for consumption.

\subsection{Sensory evaluation}

The percentages of the scores in the acceptance and rejection regions for the attributes of color, aroma, flavor, and overall impression obtained in the acceptance test of the rice, prepared with commercial tucupi and with the powdered tucupi condiment are presented in Figure 1. The highest percentages are observed in the acceptance region for all attributes assessed and for overall impression, regardless of the formulation.

Table 2 presents the mean scores attributed to the rice prepared with commercial tucupi and the rice prepared with the powdered condiment. According to Student's $t$ test at $5 \%$ significance, there was no statistically significant difference among the samples for the attributes of aroma, flavor and for overall impression. Color was the only attribute with a higher mean score for the rice prepared with the commercial tucupi. However, the mean score attributed to the rice prepared with the powdered condiment confirms that the judges were able for clearly identify the characteristic color of tucupi in the
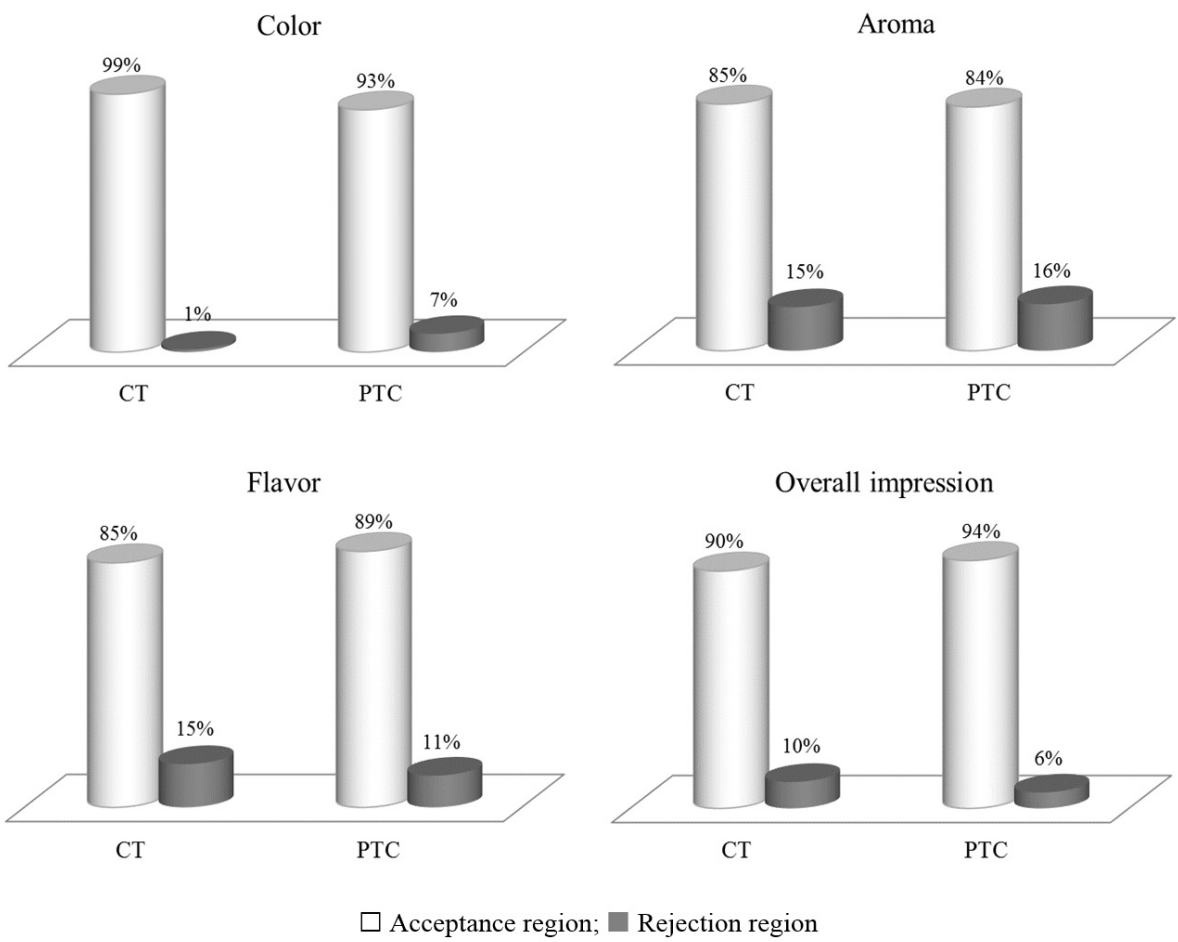

Figure 1. Histograms with the percentages of the acceptance and rejection regions regarding color, aroma, flavor, and overall impression for the rice with commercial tucupi (CT) and for the rice with the powdered tucupi condiment (PTC). 
Table 2. Mean scores attributed to the rice with commercial tucupi and the rice with the powdered tucupi condiment.

\begin{tabular}{lcc}
\hline \multicolumn{1}{c}{ Attributes } & $\begin{array}{c}\text { Rice with commercial } \\
\text { tucupi }\end{array}$ & $\begin{array}{c}\text { Rice with powdered } \\
\text { tucupi condiment }\end{array}$ \\
\hline Color & $7.8^{\mathrm{a}}$ & $7.2^{\mathrm{b}}$ \\
Aroma & $7.1^{\mathrm{a}}$ & $7.0^{\mathrm{a}}$ \\
Flavor & $7.1^{\mathrm{a}}$ & $7.1^{\mathrm{a}}$ \\
Overall impression & $7.3^{\mathrm{a}}$ & $7.3^{\mathrm{a}}$ \\
\hline
\end{tabular}

Values with the same letters on the same row do not significantly differ among themselves ( $\mathrm{p} \leq 0.05$ ) according to Student's test.

rice. The difference in color observed may be attributed to the degradation of pigments during tucupi concentration and drying, as well as the maltodextrin added in the powdered tucupi condiment. Tonon et al. (2009) also observed a decrease in the characteristic color of the açaí juice powder with the increase of maltodextrin content in the product.

Based on the acceptability index (AI) value obtained for overall impression of the rice prepared with the powdered condiment (79.7\%), it can be said that the product had favorable repercussion, because its AI for the overall impression was higher than $70 \%$ (Monteiro, 1984; Dutcosky, 2013). The purchase intention test applied to the product (Figure 2) showed a positive trend since most of the judges declared that they might purchase the product.

The sensory evaluation of the powdered tucupi condiment showed a promising possibility for the use of tucupi, given the excellent repercussion of the product prepared with this raw material. It is worth pointing out that the rice and the amounts of tucupi condiment were only used to enable the study, since the product developed could be used in any dish at appropriate amounts.

\subsection{Hygroscopic evaluation}

The moisture adsorption and desorption data at $25^{\circ} \mathrm{C}$ for the powdered tucupi condiment are presented in Table 3 , while the respective sorption isotherms are shown in Figure 3. According to the quantitative criteria proposed by Yanniotis \& Blahovec (2009) for the classification of moisture sorption isotherms, the product's adsorption isotherm behaved as type II, however, the behavior of the desorption isotherm changed and it behaved as type III. This type of change in the behavior of the adsorption and desorption isotherms, when obtained at the same temperature, is not commonly observed for foods. According to Salwin (1963), products mostly composed of biopolymers have type-II isotherms, whereas products whose main components are soluble solids have type-III isotherms. The fact the powdered tucupi condiment has virtually the same amounts of biopolymers (25.5\% starch and $9.5 \%$ proteins) and soluble solids (24\% sugar and $12 \%$ salt) suggests that the biopolymers governed the adsorption process while the soluble solids governed desorption. Type-II isotherms were observed by several authors for products derived from cassava (Santos et al., 2004; Chisté et al., 2012, 2015).

The adsorption isotherm (Figure 3) shows an exponential increase in the product's moisture content that starts at $\mathrm{a}_{\mathrm{w}}$ of 0.6 . Thus, a greater care is required to the product when stored in an

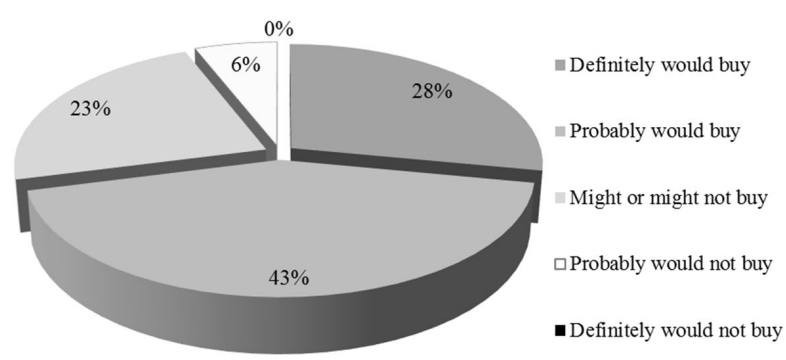

Figure 2. Intention of purchasing the powdered tucupi condiment.

Table 3. Moisture sorption data for the powdered tucupi condiment.

\begin{tabular}{|c|c|c|c|}
\hline \multicolumn{2}{|c|}{ Adsorption } & \multicolumn{2}{|c|}{ Desorption } \\
\hline$a_{w}$ & ${ }^{*} \mathrm{~m}$ & $a_{w}$ & ${ }^{*} \mathrm{~m}$ \\
\hline 0.10 & 7.70 & 0.90 & 148.42 \\
\hline 0.15 & 8.31 & 0.85 & 102.83 \\
\hline 0.20 & 8.82 & 0.80 & 77.54 \\
\hline 0.25 & 8.87 & 0.75 & 62.10 \\
\hline 0.30 & 10.02 & 0.70 & 51.64 \\
\hline 0.35 & 10.58 & 0.65 & 43.41 \\
\hline 0.40 & 11.33 & 0.60 & 37.07 \\
\hline 0.45 & 12.14 & 0.55 & 31.79 \\
\hline 0.50 & 13.46 & 0.50 & 27.83 \\
\hline 0.55 & 15.89 & 0.45 & 24.82 \\
\hline 0.60 & 20.34 & 0.40 & 23.12 \\
\hline 0.65 & 32.58 & 0.35 & 22.80 \\
\hline 0.70 & 45.91 & 0.30 & 22.43 \\
\hline 0.75 & 61.37 & 0.26 & 21.40 \\
\hline 0.80 & 77.21 & 0.20 & 21.23 \\
\hline 0.85 & 100.91 & 0.15 & 21.15 \\
\hline 0.90 & 148.42 & 0.10 & 21.03 \\
\hline
\end{tabular}

${ }^{*}$ Moisture $\left(\mathrm{g} \mathrm{H}_{2} \mathrm{O} / 100 \mathrm{~g} \mathrm{db}\right)$.

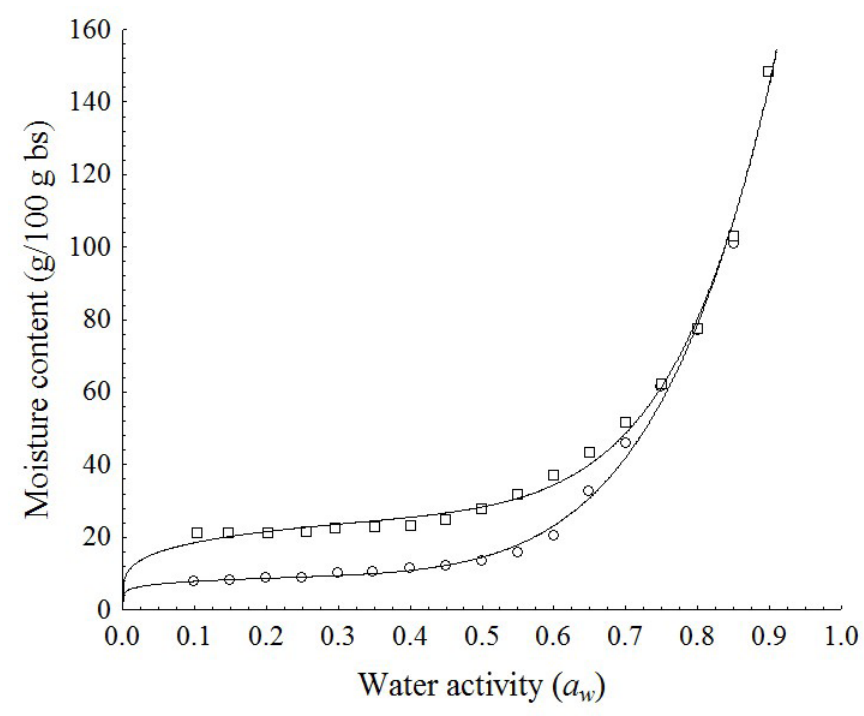

Figure 3. Adsorption ( $\circ$ ) and desorption ( $\square$ ) isotherms of the powdered tucupi condiment at $25^{\circ} \mathrm{C}$ and isotherms obtained by the Peleg model (lines). 
Table 4. Coefficient of determination $\left(\mathrm{R}^{2}\right)$, relative mean deviation (P\%), and root mean square error (RSME) obtained for the mathematical modeling of the isotherms.

\begin{tabular}{|c|c|c|c|c|c|c|}
\hline \multirow{2}{*}{ Models } & \multicolumn{3}{|c|}{ Adsorption } & \multicolumn{3}{|c|}{ Desorption } \\
\hline & $\mathrm{R}^{2}$ & $\mathrm{P}(\%)$ & RSME & $\mathrm{R}^{2}$ & $\mathrm{P}(\%)$ & RSME \\
\hline Halsey & 0.983 & 20.9 & 5.1 & 0.987 & 12.0 & 3.9 \\
\hline Henderson & 0.987 & 31.5 & 4.4 & 0.923 & 27.7 & 9.6 \\
\hline Kuhn & 0.985 & 23.7 & 4.8 & 0.995 & 7.1 & 2.3 \\
\hline Mizrahi & 0.986 & 20.6 & 4.6 & 0.996 & 6.0 & 2.1 \\
\hline Oswin & 0.986 & 24.4 & 4.6 & 0.967 & 18.3 & 6.2 \\
\hline Ferro-Fontan & 0.992 & 22.3 & 3.6 & 0.991 & 10.1 & 3.3 \\
\hline GAB & 0.990 & 26.4 & 3.9 & 0.997 & 6.2 & 2.0 \\
\hline Peleg & 0.996 & 5.2 & 2.5 & 0.996 & 5.4 & 2.3 \\
\hline
\end{tabular}

environment with $\mathrm{RH}$ above $60 \%$ to avoid undesirable changes (Assunção \& Pena, 2007). Based on the adsorption data, it can also be said that the product's microbiological stability will be ensured at $25^{\circ} \mathrm{C}\left(\mathrm{a}_{\mathrm{w}}<0.6\right)$ (Salwin, 1963; Rockland \& Nishi, 1980) when moisture level is less than $20.34 \mathrm{~g} \mathrm{H}_{2} \mathrm{O} / 100 \mathrm{~g} \mathrm{db}$ (16.90 $\mathrm{g} \mathrm{H}_{2} \mathrm{O} / 100 \mathrm{~g}$ of the product). However, the monolayer value $\left(\mathrm{m}_{\mathrm{o}}\right)$ indicates that $6.82 \mathrm{~g} \mathrm{H}_{2} \mathrm{O} / 100 \mathrm{~g} \mathrm{db}\left(6.38 \mathrm{~g} \mathrm{H}_{2} \mathrm{O} / 100 \mathrm{~g}\right.$ of the product) is the moisture level with the highest spoilage stability for the product (Rockland, 1969).

PETmet/LDPE (metallized polyethylene terephthalate/low-density polyethylene) is a film widely used as primary packaging for food products due to its lower permeability to oxygen and water vapor compared to other packaging materials (Piergiovanni, 1998; Coutinho et al., 2003). Alves et al. (2012) estimated a mean value of $0.93 \mathrm{~g} \mathrm{H}_{2} \mathrm{O} / \mathrm{m}^{2}$. day for the water vapor permeability of a PETmet/LDPE film with mean thickness of $14 \mu \mathrm{m}$ of PETmet and $58 \mu \mathrm{m}$ of LDPE when exposed to an environment with temperature at $38^{\circ} \mathrm{C}$ and $\mathrm{RH}$ of $90 \%$.

One type of packaging used to store powdered condiments is the $6.5 \mathrm{~cm} \times 4 \mathrm{~cm}$ size and holds $5 \mathrm{~g}$ of the product. Thus, considering that $5 \mathrm{~g}$ of the powdered tucupi condiment with $7.13 \%$ moisture have been stored in a packaging with those dimensions made of PETmet/LDPE film, the estimated storage time for the product to reach the threshold moisture for microbiological stability (20.34 $\mathrm{g} \mathrm{H}_{2} \mathrm{O} / 100 \mathrm{~g} \mathrm{db}$ ) would be 120 days (four months). It is noteworthy that $38^{\circ} \mathrm{C}$ and $90 \% \mathrm{RH}$ are extreme conditions for the storage of foods.

Figure 3 clearly shows the presence of a hysteresis loop between the adsorption and desorption isotherms. Hysteresis started at $0.8 \mathrm{a}_{\mathrm{w}}$ and progressively rose up to $\mathrm{a}_{\mathrm{w}}$ of 0.45 , after that it remained constant until $0.1 \mathrm{a}_{\mathrm{w}}$. In this $\mathrm{a}_{\mathrm{w}}$ range, the distance between the adsorption and desorption isotherms was $12.53 \pm 0.45 \mathrm{~g} \mathrm{H}_{2} \mathrm{O} / 100 \mathrm{~g} \mathrm{db}$. Hystereses with behavior similar to the observed for the product were not found in the scientific literature. However, according to Wolf et al. (1972), hystereses of protein- and starch-rich foods extend until low $\mathrm{a}_{\mathrm{w}}$ levels and, in the case of starch-rich foods, the distance between the sorption isotherms is more pronounced. Thus the complex structures of those macromolecules, which favor the adsorption of water molecules at low $\mathrm{a}_{\mathrm{w}}$ levels, may also have been responsible for the retention of water molecules during the product's desorption process at very low $\mathrm{a}_{\mathrm{w}}$ levels.
Table 4 presents the values of the coefficient of determination $\left(\mathrm{R}^{2}\right)$, the mean relative deviation $(\mathrm{P})$, and the root mean square error (RSME), statistical parameters used to assess the fits of mathematical models. Except for the Henderson and Oswin models, the other models presented values of $\mathrm{R}^{2}>0.98$ and the lowest RSME values, considering both adsorption and desorption processes. However, according to Peng et al. (2007), a fit is considered good, for practical purposes, when the value of $\mathrm{P}$ is below $10 \%$. Therefore, based on this criterion, the Peleg model was the only one able to predict, with good statistical precision, the moisture adsorption and desorption isotherms of the powdered tucupi condiment. The isotherms obtained by the Peleg model are presented in Figure 3.

\section{Conclusion}

Tucupi, an exotic product widely appreciated in the cuisine of the Northern Brazil, was used to prepare a powdered condiment. The product obtained a very good sensory acceptability index (80\%) and the purchase intention test (94\%) indicated that it would have excellent sales repercussion. The hygroscopic evaluation showed that the product will be more susceptible to gain moisture if it is stored in an environment with relative humidity above $60 \%$ and also indicated that $6.4 \%$ is the moisture level of highest spoilage stability for the product, although its microbiological stability is guaranteed at down to $16.9 \%$ moisture. Finally, the Peleg model proved to be very efficient on predicting the product's moisture adsorption and desorption isotherms.

\section{Acknowledgements}

The authors would like to thank $\mathrm{CNPq}$ (Conselho Nacional de Desenvolvimento Científico e Tecnológico) for the financial support (473898/2012-8).

\section{References}

Agência de Defesa Agropecuária do Estado do Pará - ADEPARÁ. (2012). Norma de identidade, qualidade, acondicionamento e rotulagem do tucupi. Belém: GIPOV.

Alves, R. M. V., Ito, D., Carvalho, J. L. V., Melo, W. F., \& Godoy, R. L. O. (2012). Stability of biofortified sweet potato flour. Brazilian Journal of Food Technology, 15(1), 59-71. http://dx.doi.org/10.1590/ S1981-67232012000100007. 
Arslan, N., \& Togrul, H. (2005). Modelling of water sorption isotherms of macaroni stored in a chamber under controlled humidity and thermodynamic approach. Journal of Food Engineering, 69(2), 133145. http://dx.doi.org/10.1016/j.jfoodeng.2004.08.004.

Association of Official Analytical Chemists - AOAC. (2010). Official methods of analysis of association of Official Analytical Chemists International (18th ed.). Arlington: AOAC.

Assunção, A. B., \& Pena, R. S. (2007). Hygroscopic behavior of the dry residue of pink shrimp. Food Science and Technology, 27(4), 786-793. http://dx.doi.org/10.1590/S0101-20612007000400018.

Bhandari, B. R., Datta, N., \& Howes, T. (2007). Problems associated with spray drying of sugar-rich foods. Drying Technology, 15(2), 671-684. http://dx.doi.org/10.1080/07373939708917253.

Borges, S., Borges, E. E. L., Correa, P. C., \& Brune, A. (2009). Hygroscopic equilibrium and viability of angico vermelho (Anadenanthera peregrina (L.) Speng) seeds under different storage environmental conditions. Scientia Forestalis, 37(84), 475-481.

Brasil, Ministério da Saúde. (2001, January 10). Regulamento técnico sobre padrões microbiológicos para alimentos ( $\mathrm{RDC} \mathrm{n}^{\circ} 12$, de 2 de janeiro de 2001). Diário Oficial [da] República Federativa do Brasil.

Brasil, Ministério da Saúde. (2003, December 23). Regulamento técnico sobre rotulagem nutricional de alimentos (RDC no 360 , de 23 de dezembro 2003). Diário Oficial [da] República Federativa do Brasil.

Brasil, Ministério da Saúde. (2005, September 23). Regulamento técnico para especiarias, temperos e molhos (RDC n² 276 , de 22 de setembro de 2005). Diário Oficial [da] República Federativa do Brasil.

Brunauer, S., Emmett, T. H., \& Teller, F. (1938). Adsorption of gases in multimolecular layers. Journal of the American Chemical Society, 60(2), 309-319. http://dx.doi.org/10.1021/ja01269a023.

Chirife, J., \& Favetto, G. J. (1992). Some physico-chemical basis of food preservation by combined methods. Food Research International, 25(5), 389-396. http://dx.doi.org/10.1016/0963-9969(92)90114-K.

Chirife, J., \& Iglesias, H. A. (1978). Equations for fitting water sorption isotherms of foods. Part 1: a review. Journal of Food Technology, 13(3), 159-174. http://dx.doi.org/10.1111/j.1365-2621.1978.tb00792.x.

Chirife, J., Boquet, R., Fontán, C. F., \& Iglesias, H. A. (1983). A new model for describing the water sorption isotherm of foods. Journal of Food Science, 48(4), 1382-1383. http://dx.doi.org/10.1111/j.1365-2621.1983. tb09245.x.

Chisté, R. C., Cardoso, J. M., Silva, D. A., \& Pena, R. S. (2015). Hygroscopic behaviour of cassava flour from dry and water groups. Ciência Rural, 45(8), 1515-1521. http://dx.doi.org/10.1590/0103-8478cr20140338.

Chisté, R. C., Cohen, K. O., \& Oliveira, S. S. (2007). Study of tucupi physicochemical properties. Food Science and Technology, 27(3), 437-440. http://dx.doi.org/10.1590/S0101-20612007000300002.

Chisté, R. C., Silva, P., Lopes, A., \& Pena, R. S. (2012). Sorption isotherms of tapioca flour. International Journal of Food Science \& Technology, 47(4), 870-874. http://dx.doi.org/10.1111/j.1365-2621.2011.02900.x.

Companhia Nacional de Abastecimento - CONAB. (2016). Mandioca: safra 03/2016. Brasília: CONAB. Retrieved from http://www.conab. gov.br

Corrêa, P. C., Botelho, F. M., Botelho, S. C. C., \& Goneli, A. L. D. (2014). Sorption isotherms of fruits of Coffea canephora. Revista Brasileira de Engenharia Agrícola e Ambiental, 18(10), 1047-1052. http://dx.doi. org/10.1590/1807-1929/agriambi.v18n10p1047-1052.

Coutinho, F. M. B., Mello, I. L., \& Santa Maria, L. C. (2003). Polyethylene: main types, properties and applications. Polímeros: Ciência e Tecnologia, 13(1), 1-13. http://dx.doi.org/10.1590/S0104-14282003000100005.
Della Lucia, S. M. (2008). Métodos estatísticos para avaliação da influência de características não sensoriais na aceitação, intenção de compra e escolha do consumidor (Ph.D. thesis). Universidade Federal de Viçosa, Viçosa.

Dova, M. I., Petrotos, K. B., \& Lazarides, H. N. (2007). On the direct osmotic concentration of liquid foods. Part I. Impact of process parameters on process performance. Journal of Food Engineering, 78(2), 422-430. http://dx.doi.org/10.1016/j.jfoodeng.2005.10.010.

Doymaz, I. (2011). Drying of pomegranate arils and selection of a suitable drying model. Food Biophysics, 6(4), 461-467. http://dx.doi. org/10.1007/s11483-011-9226-z.

Dutcosky, S. D. (2013). Análise sensorial de alimentos (4th ed.). Curitiba: Champagnat.

Food and Agriculture Organization of the United Nations - FAO. (2013). FAOSTAT: statistical database. Rome: FAO. Retrieved from http://faostat.fao.org

Jaya, S., \& Das, H. (2004). Effect of maltodextrin, glycerol monostearate and tricalcium phosphate on vacuum dried mango powders properties. Journal of Food Engineering, 63(2), 125-134. http:// dx.doi.org/10.1016/S0260-8774(03)00135-3.

Lebot, V. (2009). Tropical root and tuber crops: cassava, sweet potato, yams and aroids. Oxford: CAB International.

Lomauro, C. J., Bakshi, A. S., \& Labuza, T. P. (1985). Evaluation of food moisture sorption isotherm equations. Part I. Fruit, vegetable and meat products. Lebensmittel-Wissenchaft und Technologie, 18(2), 111-117.

Maroulis, Z. B., Tsami, E., Marinos-Kouris, D., \& Saravacos, G. D. (1988). Application of the GAB model to the moisture sorption isotherms for dried fruits. Journal of Food Engineering, 7(1), 63-70. http://dx.doi.org/10.1016/0260-8774(88)90069-6.

McLellan, M. R., Lind, L. R., \& Kime, R. W. (1995). Hue angle determinations and statistical analysis for multiquadrant hunter L, a, b data. Journal of Food Quality, 18(3), 235-240. http://dx.doi. org/10.1111/j.1745-4557.1995.tb00377.x.

Minim, V. P. R. (2013). Análise sensorial: estudos com consumidores. Viçosa: Editora UFV.

Monteiro, C. L. B. (1984). Técnicas de avaliação sensorial (2nd ed.). Curitiba: CEPPA-UFPR.

Peleg, M. (1993). Assessment of a semi-empirical four parameter general model for sigmoid moisture sorption isotherms. Journal of Food Process Engineering, 16(1), 21-37. http://dx.doi.org/10.1111/j.1745-4530.1993. tb00160.x.

Peng, G., Chen, X., Wu, W., \& Jiang, X. (2007). Modeling of water sorption isotherm for corn starch. Journal of Food Engineering, 80(2), 562-567. http://dx.doi.org/10.1016/j.jfoodeng.2006.04.063.

Piergiovanni, L. (1998). Materiais de embalagem e tecnologias de envase. In R. Baruffaldi \& M. N. Oliveira (Eds.), Fundamentos de tecnologia de alimentos (pp. 219-278). São Paulo: Atheneu.

Rockland, L. B. (1969). Water activity and storage stability. Food Technology, 23(1), 1241-1251.

Rockland, L. B., \& Nishi, S. K. (1980). Influence of water activity on food product quality and stability. Food Technology, 34(1), 42-59.

Rodriguez-Amaya, D. A. (2001). Guide to carotenoides analysis in food. Washington: International Life Sciences Institute Press.

Salwin, H. (1963). Moisture levels required for stability in dehydrated foods. Food Technology, 17(9), 1114-1121.

Samapundo, S., Devlieghere, F., Meulenaer, B., Atukwase, A., Lamboni, Y., \& Debevere, J. (2007). Sorption isotherms and isosteric heats of 
sorption of whole yellow dent corn. Journal of Food Engineering, 79(1), 168-175. http://dx.doi.org/10.1016/j.jfoodeng.2006.01.040.

Santos, F. S. A., Figueirêdo, R. M. F., \& Queiroz, A. J. M. (2004). Moisture adsorption isotherms of spiced cassava flour. Revista Brasileira de Produtos Agroindustriais, 6(2), 149-155. http://dx.doi. org/10.15871/1517-8595/rbpa.v6n2p149-155.

Santos, V. F. N., \& Pascoal, G. B. (2013). General aspects of the food culture of the State of Para. Revista da Associação Brasileira de Nutrição, 5(1), 73-80.

Sève, R. (1991). New formula for the computation of CIE 1976 hue difference. Color Research and Application, 16(3), 217-218. http:// dx.doi.org/10.1002/col.5080160311.

Smith, S. D. (2014). Quantifying color variation: improved formulas for calculating hue with segment classification. Applications in Plant Sciences, 2(3), 1-7. PMid:25202612. http://dx.doi.org/10.3732/ apps. 1300088 .

Spohrer, R., Larson, M., Maurin, C., Laillou, A., Capanzana, M., \& Garrett, G. S. (2013). The growing importance of staple foods and condiments used as ingredients in the food industry and implications for large-scale food fortification programs in Southeast Asia. Food and Nutrition Bulletin, 34(2, Suppl), 50-61. PMid:24049996. http:// dx.doi.org/10.1177/15648265130342S107.

Ssemakula, G., Dixon, A. G. O., \& Maziya-Dixon, B. (2007). Stability of total carotenoid concentration and fresh yield of selected yellow-fleshed cassava (Manihot esculenta Crantz). Journal of Tropical Agriculture, 45(6), 14-20. http://dx.doi.org/10.2135/cropsci2013.02.0123.

Tonon, R. V., Brabet, C., \& Hubinger, M. D. (2009). Influence of drying air temperature and carrier agent concentration on the physicochemical properties of açai juice powder. Food Science and Technology, 29(2), 444-450. http://dx.doi.org/10.1590/S0101-20612009000200034.

Treyball, R. B. (1980). Mass transfer operations (3th ed.). New York: McGraw-Hill.

Tunç, S., \& Duman, O. (2007). Thermodynamic properties and moisture adsorption isotherms of cottonseed protein isolate and different forms of cottonseed samples. Journal of Food Engineering, 81(1), 133-143. http://dx.doi.org/10.1016/j.jfoodeng.2006.10.015.

Viuda-Martos, M., Ruiz-Navajas, Y., Fernández-López, J., \& PérezÁlvarez, J. (2011). Spices as functional foods. Critical Reviews in Food Science and Nutrition, 51(1), 13-28. PMid:21229415. http:// dx.doi.org/10.1080/10408390903044271.

Wolf, M., Walker, J. E., \& Kapsalis, J. G. (1972). Water vapor sorption hysteresis in dehydrated food. Journal of Agricultural and Food Chemistry, 20(5), 1073-1077. http://dx.doi.org/10.1021/jf60183a021.

Yanniotis, S., \& Blahovec, J. (2009). Model analysis of sorption isotherms. Lebensmittel-Wissenschaft + Technologie, 42(10), 1688-1695. http:// dx.doi.org/10.1016/j.lwt.2009.05.010. 